\title{
Associations between daily mortality in London and combined oxidant capacity, ozone and nitrogen dioxide
}

\author{
M. L. Williams • R. W. Atkinson • H. R. Anderson • \\ F. J. Kelly
}

Received: 6 September 2013 / Accepted: 27 February 2014 /Published online: 22 March 2014

(C) The Author(s) 2014. This article is published with open access at Springerlink.com

\begin{abstract}
Both nitrogen dioxide $\left(\mathrm{NO}_{2}\right)$ and ozone $\left(\mathrm{O}_{3}\right)$ are powerful oxidants in ambient air that are intimately linked through atmospheric chemistry and which continuously interchange over very short timescales. Based upon atmospheric chemistry alone, there is a strong, a priori, reason for considering $\mathrm{O}_{3}$ and $\mathrm{NO}_{2}$ together in epidemiological studies, rather than either of the two pollutants separately in single-pollutant models. This paper compares two approaches to this, using $\mathrm{O}_{\mathrm{x}}$, defined as $\mathrm{O}_{3}+\mathrm{NO}_{2}$, as a single metric and also using $\mathrm{O}_{3}$ and $\mathrm{NO}_{2}$ together in two-pollutant models. We hypothesised that the magnitude of the association between $\mathrm{O}_{\mathrm{x}}$ and daily mortality would be greater than for $\mathrm{NO}_{2}$ and $\mathrm{O}_{3}$ individually. Using collocated hourly measurements for $\mathrm{O}_{3}$ and $\mathrm{NO}_{2}$ in London, from 2000 to 2005, we carried out a time series analysis of daily mortality. We investigated $\mathrm{O}_{3}, \mathrm{NO}_{2}$ and $\mathrm{O}_{\mathrm{x}}$ individually in single-pollutant Poisson regression models and $\mathrm{NO}_{2}$ and $\mathrm{O}_{3}$ jointly in two-pollutant models in both all-year and season-specific analyses. We observed larger associations for mean 24-h concentrations of $\mathrm{O}_{\mathrm{x}}(1.30 \%$ increase in mortality
\end{abstract}

Electronic supplementary material The online version of this article (doi:10.1007/s11869-014-0249-8) contains supplementary material, which is available to authorized users.

M. L. Williams $(\bowtie)$

MRC-PHE Centre for Environment and Health, Kings College London, Room 4.129 Franklin Wilkins Building, 150 Stamford Street, London SE1 9NH, UK

e-mail: martin.williams@kcl.ac.uk

R. W. Atkinson · H. R. Anderson

Public Health Research Institute and MRC-PHE Centre for

Environment and Health, St George's, University of London,

London, UK

H. R. Anderson · F. J. Kelly

MRC-PHE Centre for Environment and Health, Kings College

London, Franklin Wilkins Building, 150 Stamford Street,

London SE1 9NH, UK per $10 \mathrm{ppb})$ than for $\mathrm{O}_{3}(0.87 \%)$ and $\mathrm{NO}_{2}(0 \%)$ individually. However, when analysed jointly in two-pollutant models, associations for $\mathrm{O}_{3}(1.54 \%)$ and $\mathrm{NO}_{2}(1.07 \%)$ were comparable to the $\mathrm{O}_{\mathrm{x}}$ association. Season-specific analyses broadly followed this pattern irrespective of whether the $\mathrm{O}_{\mathrm{x}}$ concentrations were driven by $\mathrm{O}_{3}$ production (summer) or depletion (winter). This novel approach in air pollution epidemiology captures the simultaneous impact of both oxidants whilst avoiding many of the statistical issues associated with two-pollutant models and potentially simplifies health impact calculations.

Keywords Time series $\cdot$ Mortality $\cdot$ Oxidants $\cdot$ Ozone . Nitrogen dioxide

\section{Introduction}

Epidemiological time series studies have reported positive associations between outdoor daily concentrations of ozone and nitrogen dioxide and daily counts of health events such as death and admission to hospital (Anderson et al. 2007; WHO 2013). These associations have typically been assessed using regression models incorporating each pollutant individually. It is well known that ozone $\left(\mathrm{O}_{3}\right)$ and nitrogen dioxide $\left(\mathrm{NO}_{2}\right)$, in conjunction with nitric oxide (NO), react together and interchange $\mathrm{O}_{3}$ and $\mathrm{NO}_{2}$ over a timescale typically of minutes during daytime (Seinfeld and Pandis 2006). The $\mathrm{O}_{3} / \mathrm{NO}_{\mathrm{x}}$ system is characterised by the following equations:

$$
\begin{aligned}
& \mathrm{O}_{3}+\mathrm{NO}=\mathrm{NO}_{2}+\mathrm{O}_{2} \\
& \mathrm{NO}_{2}+\mathrm{h} v=\mathrm{NO}+\mathrm{O} \\
& \mathrm{O}+\mathrm{O}_{2}=\mathrm{O}_{3}
\end{aligned}
$$


where $\mathrm{h} \nu$ is a photon causing photolysis of $\mathrm{NO}_{2}$. This reaction scheme is closed in the sense that there is no net production or loss of $\mathrm{O}_{3}$. At night, or in the absence of sunlight, such as on some winter days, there is no photolysis and reaction (Eq. 2) does not occur. In these situations, if there is sufficient NO, as there usually is in large urban areas, all the ozone is converted to $\mathrm{NO}_{2}$ and ozone concentrations are very low or even zero.

There is an important point to note here. These reactions are all relatively fast and constantly interchange $\mathrm{O}_{3}$ and $\mathrm{NO}_{2}$ very quickly such that, in the absence of other reactions (such as occur in 'smog' episodes) and fresh injection of emissions, the sum of $\mathrm{O}_{3}$ and $\mathrm{NO}_{2}$ is constant, denoted by $\mathrm{O}_{\mathrm{x}}=\mathrm{O}_{3}+\mathrm{NO}_{2}$ (Van Egmond and Kesseboom 1985; Clapp and Jenkin 2001). From an atmospheric chemistry point of view, therefore, it would seem appropriate to investigate the combination of $\mathrm{O}_{3}$ and $\mathrm{NO}_{2}$ together, as the 'conserved' pollutant $\mathrm{O}_{\mathrm{x}}$. An illustration of the atmospheric chemistry and the very close relationship between $\mathrm{O}_{3}$ and $\mathrm{NO}_{2}$ and $\mathrm{O}_{\mathrm{x}}$ during the high ozone episode in August 2003 is shown in Fig. S1. This figure, particularly through consideration of the ratio $\mathrm{O}_{3} / \mathrm{O}_{\mathrm{x}}$, demonstrates the rapid interchange of $\mathrm{O}_{3}$ and $\mathrm{NO}_{2}$ over quite short timescales within a day.

Given this dynamic relationship between $\mathrm{O}_{3}$ and $\mathrm{NO}_{2}$, it is surprising that relatively few time series studies have assessed the health associations of these pollutants jointly using twopollutant models (Touloumi et al. 1997; Burnett et al. 1998; Gryparis et al. 2004; Simpson et al. 2005; Samoli et al. 2006; HEI 2010). Only a single study of respiratory hospital admissions in Paris has considered $\mathrm{O}_{\mathrm{x}}$ as a measure of combined oxidative capacity (Chardon et al. 2007). This paper, however, focussed on different metrics for ozone alone. Using collocated measurements for $\mathrm{O}_{3}$ and $\mathrm{NO}_{2}$ in London, we carried out a time series analysis to investigate the relationships between daily measures of $\mathrm{O}_{3}, \mathrm{NO}_{2}$ and $\mathrm{O}_{\mathrm{x}}$ and daily all-cause mortality. We hypothesised that despite the dynamic interchange of $\mathrm{O}_{3}$ and $\mathrm{NO}_{2}$, the magnitude of the association between $\mathrm{O}_{\mathrm{x}}$ and mortality would be greater than for $\mathrm{NO}_{2}$ and $\mathrm{O}_{3}$ individually. We also compared the $\mathrm{O}_{\mathrm{x}}$ associations with the associations for $\mathrm{O}_{3}$ and $\mathrm{NO}_{2}$ estimated from two-pollutant models.

\section{Methods}

Details of deaths in England and Wales were obtained from the Office for National Statistics. From these records, daily counts of deaths from all non-accidental causes (ICD-10 Chapters A$\mathrm{R})$ for people resident and dying in London between 1 January 2000 and 31 December 2005 were constructed. Hourly concentrations of $\mathrm{NO}_{2}$ and $\mathrm{O}_{3}$ were obtained from ten collocated background monitoring stations across London operating during the study period from Defra's monitoring network and converted from microgram per cubic metre to parts per billion (ppb) using factors of 1.91 and 2 (at $20 \mathrm{C}$ and $1,013 \mathrm{mb}$ ) for $\mathrm{NO}_{2}$ and $\mathrm{O}_{3}$, respectively. Hourly $\mathrm{O}_{\mathrm{x}}$ concentrations at each site were calculated from the addition of the hourly $\mathrm{NO}_{2}$ and $\mathrm{O}_{3}$ concentrations. Daily maximum 1-h and mean 24-h (abbreviated to 1-h and 24-h, respectively, hereafter) concentrations of $\mathrm{NO}_{2}, \mathrm{O}_{3}$ and $\mathrm{O}_{\mathbf{x}}$ were then calculated for each site. Missing values for each pollutant at each site were imputed, in turn, from regression models incorporating daily measures from all monitors and indicators of month and season. London-wide daily 1- and 24-h averages for each pollutant were then calculated by averaging across sites. Daily average temperature and dew point temperature for London (Holborn, a location in central London) were obtained from the British Atmospheric Data Centre website (http://badc.nerc.ac.uk).

We used a Poisson model of daily mortality counts with seasonal patterns modelled as a penalised spline of time with 8 degrees of freedom per year. The model also included natural cubic splines for average daily temperature on the same day and lagged by 1 day (lag 1) and indicator variables for day of week and public holidays. We also stratified our analyses by season (December-February, March-May, June-August and September-November). Each pollutant lagged by 1 day was entered into the models singly $\left(\mathrm{NO}_{2}, \mathrm{O}_{3}\right.$ and $\left.\mathrm{O}_{\mathrm{x}}\right)$ and for $\mathrm{NO}_{2}$ and $\mathrm{O}_{3}$ jointly in two-pollutant models. To assess the shape of the concentration response function for $\mathrm{O}_{3}$ and $\mathrm{NO}_{2}$ in the allyear data, we explored the shape of the concentration response function for each pollutant individually using natural cubic splines with 3 degrees of freedom. To assess the relationship between mortality and $\mathrm{NO}_{2}$ and $\mathrm{O}_{3}$ jointly, we modelled the concentration response surface using a bivariate smoothing spline (Wood 2006). As a sensitivity analysis in the all-year model, we incorporated longer lags for temperature (lags 2-6). Relative risks (RR) and $95 \%$ confidence intervals were expressed as percentage changes (100*RR-1) associated with $10 \mathrm{ppb}$ and interquartile range (IQR) increases in pollutant concentrations. The $\mathrm{R}$ statistical package was used for all analyses (R, Development Core team 2007).

\section{Results}

Summary statistics for daily mortality counts, $\mathrm{O}_{3}, \mathrm{NO}_{2}$ and $\mathrm{O}_{\mathrm{x}}$ and temperature, are shown in Table 1. The median number of deaths in London during the study period was 145 per day. One hour concentrations of $\mathrm{O}_{3}$ and $\mathrm{NO}_{2}$ ranged from 1.7 to $103.9 \mathrm{ppb}$ (interquartile range $(\mathrm{IQR})=13.3 \mathrm{ppb}$ ) and from 9.0 to $81.3 \mathrm{ppb}$ $\left(\mathrm{IQR}=12.5 \mathrm{ppb}\right.$ ), respectively. One hour $\mathrm{O}_{\mathrm{x}}$ concentrations were, as expected, higher; range 25 to $123.5 \mathrm{ppb}$ (IQR=10.6 ppb). Twenty-four hour concentrations of each pollutant had a much lower range reaching maximum values of 55.2, 52.0 and $77.1 \mathrm{ppb}$ for $\mathrm{O}_{3}, \mathrm{NO}_{2}$ and $\mathrm{O}_{\mathrm{x}}$, respectively. Summary statistics for each pollutant by season are shown in Table S1.

One hour concentrations of $\mathrm{NO}_{2}$ and $\mathrm{O}_{3}$ were weakly, negatively correlated (Spearman rank correlation coefficient, $r=-0.1$ ), whereas the 24-h concentrations showed a stronger, 
Table 1 Summary statistics for daily counts of all-cause mortality, daily mean temperature and daily maximum 1 -h and mean $24-\mathrm{h}$ concentrations of ozone $\left(\mathrm{O}_{3}\right)$, nitrogen dioxide $\left(\mathrm{NO}_{2}\right)$ and combined oxidant $\left(\mathrm{O}_{\mathrm{x}}\right)$

\begin{tabular}{lcccccc}
\hline Variable & $\mathrm{Min}^{\mathrm{a}}$ & $\mathrm{Q1}^{\mathrm{b}}$ & $\mathrm{Med}^{\mathrm{c}}$ & $\mathrm{Q}^{\mathrm{d}}$ & $\mathrm{Max}^{\mathrm{f}}$ & $\mathrm{IQR}^{\mathrm{e}}$ \\
\hline Mortality (n/day) & 96 & 133 & 145 & 159 & 302 & 26 \\
Temperature $\left({ }^{\circ} \mathrm{C}\right)$ & -0.2 & 8.4 & 12.1 & 16.5 & 29.3 & 8.1 \\
Pollutants (ppb) & & & & & & \\
$1 \mathrm{~h}$ & & & & & & \\
$\mathrm{O}_{3}$ & 1.7 & 23.4 & 29.9 & 36.6 & 103.9 & 13.3 \\
$\mathrm{NO}_{2}$ & 9.0 & 28 & 34.2 & 40.5 & 81.3 & 12.5 \\
$\mathrm{O}_{\mathrm{x}}$ & 25.0 & 42.9 & 47.5 & 53.5 & 123.5 & 10.6 \\
$24 \mathrm{~h}$ & & & & & & \\
$\mathrm{O}_{3}$ & 0.9 & 10.4 & 16.5 & 21.9 & 55.2 & 11.5 \\
$\mathrm{NO}_{2}$ & 5.9 & 16.2 & 20.4 & 25.3 & 52.0 & 9.2 \\
$\mathrm{O}_{\mathrm{x}}$ & 17.4 & 34.6 & 38.1 & 42.3 & 77.1 & 7.7 \\
\hline
\end{tabular}

Notes: ${ }^{\text {a }}$ Minimum; ${ }^{\mathrm{b}}$ 25th percentile; ${ }^{\mathrm{c}}$ Median; ${ }^{\mathrm{d}}$ 75th percentile; ${ }^{\mathrm{e}}$ Maximum; ${ }^{\mathrm{f}}$ Interquartile range

negative correlation (Table 2). $\mathrm{O}_{\mathrm{x}}$ concentrations were more strongly correlated with $\mathrm{O}_{3}$ than with $\mathrm{NO}_{2}$. The scatter plot of 1-h concentrations of $\mathrm{NO}_{2}$ and $\mathrm{O}_{3}$ (Fig. 1a) illustrates two different relationships between the pollutants: a negative relationship below about $35 \mathrm{ppb}$ and a positive correlation above. The negative correlation below $35 \mathrm{ppb}$ was also evident in the 24-h measures (Fig. 1b), and the few data points above $35 \mathrm{ppb}$ suggested a positive relationship. Scatter plots and correlation statistics for the pollutants, both 1- and 24-h, by season are given in Figs. S2-S5 and Tables S2-S5. One hour $\mathrm{O}_{3}$ and $\mathrm{NO}_{2}$ concentrations were negatively correlated in all periods of the year except summer when the pollutants were positively correlated $(r=0.51)$. A similar pattern was observed for 24-h concentrations, although the negative correlations were stronger than for 1 -h measures (e.g. -0.71 vs. -0.11 in months March-May) and the positive correlation in the summer months was weaker ( 0.08 vs. 0.51$)$. During summer months, 1-h $\mathrm{O}_{\mathrm{x}}$ concentrations were driven by $\mathrm{O}_{3}(r=0.93)$; whereas

Table 2 Spearman rank correlations coefficients between daily maximum 1-h and mean 24-h concentrations of ozone $\left(\mathrm{O}_{3}\right)$, nitrogen dioxide $\left(\mathrm{NO}_{2}\right)$ and combined oxidant $\left(\mathrm{O}_{\mathrm{x}}\right)$

\begin{tabular}{|c|c|c|c|c|c|c|}
\hline \multirow[t]{2}{*}{ Pollutant } & $\mathrm{O}_{3}$ & $\mathrm{NO}_{2}$ & $\mathrm{O}_{\mathrm{X}}$ & $\mathrm{O}_{3}$ & $\mathrm{NO}_{2}$ & $\mathrm{O}_{\mathrm{X}}$ \\
\hline & $1 \mathrm{~h}$ & & & $24 \mathrm{~h}$ & & \\
\hline
\end{tabular}

\begin{tabular}{cllllll}
\hline $1 \mathrm{~h}$ & & & & & & \\
$\mathrm{O}_{3}$ & 1.00 & & & & & \\
$\mathrm{NO}_{2}$ & -0.10 & 1.00 & & & & \\
$\mathrm{O}_{\mathrm{X}}$ & 0.63 & 0.56 & 1.00 & & & \\
$24 \mathrm{~h}$ & & & & & & \\
$\mathrm{O}_{3}$ & 0.87 & -0.40 & 0.39 & 1.00 & & \\
$\mathrm{NO}_{2}$ & -0.30 & 0.90 & 0.43 & -0.57 & 1.00 & \\
$\mathrm{O}_{\mathrm{X}}$ & 0.69 & 0.45 & 0.91 & 0.56 & 0.33 & 1.00 \\
\hline
\end{tabular}

during winter months, they were driven by $\mathrm{NO}_{2}$ concentrations $(r=0.76)$. In spring and autumn, even though the overall correlations were negative, at higher ozone levels (above $\sim 35 \mathrm{ppb}$ ), there is an indication in both seasons of a positive correlation in periods of photochemically generated $\mathrm{O}_{3}$ as found in the summer months (Figs. S3 and S5).

Results from Poisson regression models for mortality and 1- and 24-h $\mathrm{O}_{3}, \mathrm{NO}_{2}$ and $\mathrm{O}_{\mathrm{x}}$ and two-pollutant models for $\mathrm{O}_{3}$ and $\mathrm{NO}_{2}$ are shown in Fig. 2, expressed per 10 ppb and per IQR (the corresponding regression estimates and standard errors per parts per billion are tabulated in Table S6). In single-pollutant models, the association (expressed per $10 \mathrm{ppb})$ for 1-h $\mathrm{O}_{3}$ was larger than for $\mathrm{NO}_{2}(0.68 \mathrm{vs}$. $0.24 \%$ ) with the $\mathrm{O}_{\mathrm{x}}$ association between the two $(0.42 \%)$, although the confidence intervals for each of the three associations overlapped substantially. In two-pollutant models for the 1-h metric, the mutually adjusted associations for $\mathrm{O}_{3}$ and $\mathrm{NO}_{2}$ were 0.73 and $0.33 \%$, respectively. The pattern for the 24-h metrics was different however. In single-pollutant models, the association between $\mathrm{O}_{\mathrm{x}}$ and mortality $(1.30 \%$ per $10 \mathrm{ppb}$ ) was larger than the single-pollutant model results for $\mathrm{O}_{3}$ and $\mathrm{NO}_{2}(0.87$ and $0 \%$, respectively). The twopollutant $\left(\mathrm{O}_{3}\right.$ and $\left.\mathrm{NO}_{2}\right)$ model associations were 1.54 and $1.07 \%$, respectively.

Results for individual seasons are illustrated in Figs. S6-S9 with the corresponding regression estimates and standard errors tabulated in Table S6. In summer, and to a lesser extent, during autumn months, $\mathrm{O}_{3}$ associations were larger than for $\mathrm{NO}_{2}$ and dominated the two-pollutant models. During spring (months March to May), all pollutants were positively associated with all-cause mortality but no associations were observed during winter months. We found that in both the allyear and season-specific analyses, the size of the $\mathrm{O}_{\mathrm{x}}$ associations were generally in between those for $\mathrm{O}_{3}$ and $\mathrm{NO}_{2}$ estimated from two-pollutant models whether dominated by $\mathrm{O}_{3}$ as during the summer months or $\mathrm{NO}_{2}$ as during the spring months. Scaling all associations for the IQRs gave a broadly similar pattern of results.

Figure 3 illustrates the concentration response functions for 24-h averages of $\mathrm{O}_{3}, \mathrm{NO}_{2}$ and $\mathrm{O}_{\mathrm{x}}$ in single-pollutant models, and the concentration response surface for $\mathrm{O}_{3}$ and $\mathrm{NO}_{2}$ modelled jointly. A clear nonlinear relationship with mortality was observed for $\mathrm{O}_{3}$ (plot a) but not $\mathrm{NO}_{2}$ (plot b) -relationships that persisted upon mutual adjustment (plot d). The concentration-response function for $\mathrm{O}_{\mathrm{x}}$ (plot c) was also suggestive of a nonlinear relationship.

\section{Discussion}

Summary of findings Our time series analysis of daily mortality and daily concentrations of $\mathrm{O}_{3}, \mathrm{NO}_{2}$ and combined oxidant $\left(\mathrm{O}_{\mathrm{x}}\right)$ derived from the simple addition of $\mathrm{O}_{3}$ and 
Fig. 1 Scatter plot of daily maximum 1-h and mean 24-h nitrogen dioxide and ozone concentrations (ppb) in London between 1 January 2000 and 31 December 2005. a 1 h. b $24 \mathrm{~h}$ a) $1-\mathrm{hr}$

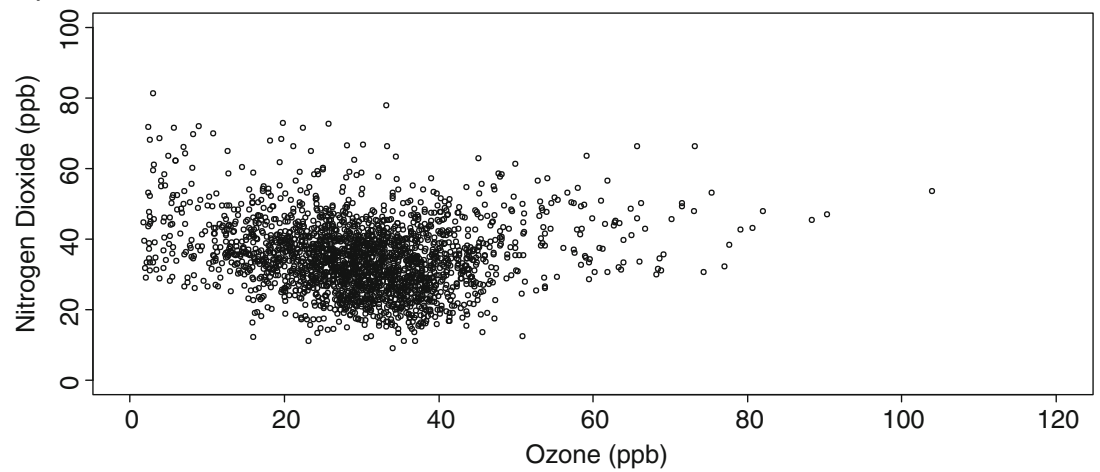

b) 24-hr

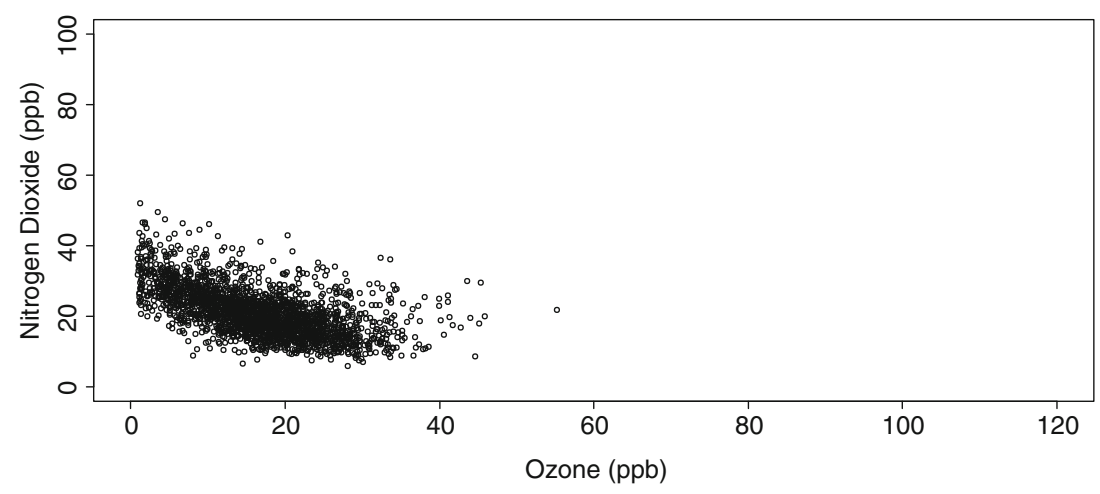

$\mathrm{NO}_{2}$ revealed: (1) larger associations with mortality for 24-h concentrations of $\mathrm{O}_{x}$ than for $\mathrm{O}_{3}$ and $\mathrm{NO}_{2}$ individually; (2) stronger associations for both $\mathrm{O}_{3}$ and $\mathrm{NO}_{2}$ when analysed jointly in two-pollutant models compared to individual associations from single-pollutant models and (3) associations for $\mathrm{O}_{\mathrm{x}}$ and for $\mathrm{O}_{3}$ and $\mathrm{NO}_{2}$ in two-pollutant models were larger for 24-h measures than for 1-h measures. In summer, and to a lesser extent during autumn months, ozone associations dominated the two-pollutant models; whereas during spring, both $\mathrm{O}_{3}$ and $\mathrm{NO}_{2}$ were positively associated with all-cause mortality. During these months, the $\mathrm{O}_{\mathrm{x}}$ associations were similar to the $\mathrm{O}_{3}$ associations. No associations were observed during winter months for any of the pollutants.

$O_{x}$ results Our descriptive analyses of daily concentrations of $\mathrm{O}_{3}$ and $\mathrm{NO}_{2}$ illustrate clearly the interrelation between the two pollutants and the two regions of $\mathrm{O}_{\mathrm{x}}$ formation. Below hourly average concentrations of about $35 \mathrm{ppb}$, a typical tropospheric background ozone concentration (Monks et al. 2009), the 'titration' reaction (Eq. 1) dominates and ozone and $\mathrm{NO}_{2}$ are negatively correlated. Above this value, ozone tends to be produced photochemically and more complex reactions take place in addition to reactions (Eqs. 1-3) with the result that $\mathrm{O}_{3}$ and $\mathrm{NO}_{2}$ were positively correlated. The scatter plots and correlations statistics for the two pollutants by season illustrate both the productive nature of the relationship (e.g. during summer months) and the destructive nature (e.g. winter months). This strong interrelationship of the two pollutants with correlations that vary in direction and magnitude by season suggests that analyses of each pollutant separately will not characterise well the combined oxidative stress on the population from simultaneous exposure to the two pollutants. This observation appears to be supported by our finding that associations with mortality were larger for 24-h values of $\mathrm{O}_{\mathrm{x}}$ than for $\mathrm{O}_{3}$ and $\mathrm{NO}_{2}$ from single-pollutant models.

Single- and two-pollutant model results A substantial epidemiological time series literature has demonstrated associations between $\mathrm{O}_{3}$ and $\mathrm{NO}_{2}$ and mortality in single-pollutant models (Anderson et al. 2007; WHO 2013). However, only a relatively small number of time series studies of all-age, all-cause mortality (all season) have considered $\mathrm{O}_{3}$ and $\mathrm{NO}_{2}$ jointly in two-pollutant models. In Europe, the APHEA-1 and -2 projects investigated both pollutants, initially in six cities (Touloumi et al. 1997) and then for $21\left(\mathrm{O}_{3}\right)$ and $30\left(\mathrm{NO}_{2}\right)$ European cities (Gryparis et al. 2004; Samoli et al. 2006). The initial investigation used 1-h measures of each pollutant and reported a small increase in both risk estimates when the pollutants were considered simultaneously in two-pollutant models compared with single-pollutant models. This contrasted with the summer only analysis in the later study where the summary effect estimate for 1-h ozone reduced by one third upon adjustment for $1-\mathrm{h} \mathrm{NO}_{2}$ concentrations (no adjusted $\mathrm{NO}_{2}$ coefficient reported). The analysis of 1-h $\mathrm{NO}_{2}$ in 


\section{a) Per $10 \mathrm{ppb}$}

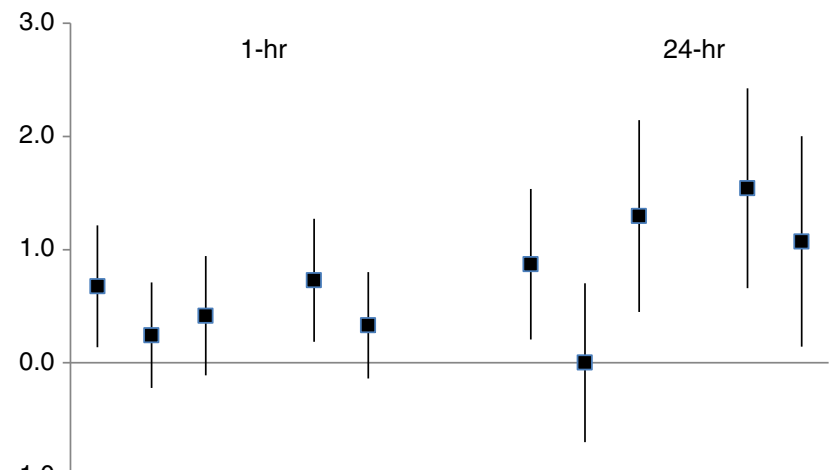

O3 NO2 Ox O3 NO2

O3 NO2 Ox

O3 NO2

b) Per interquartile range

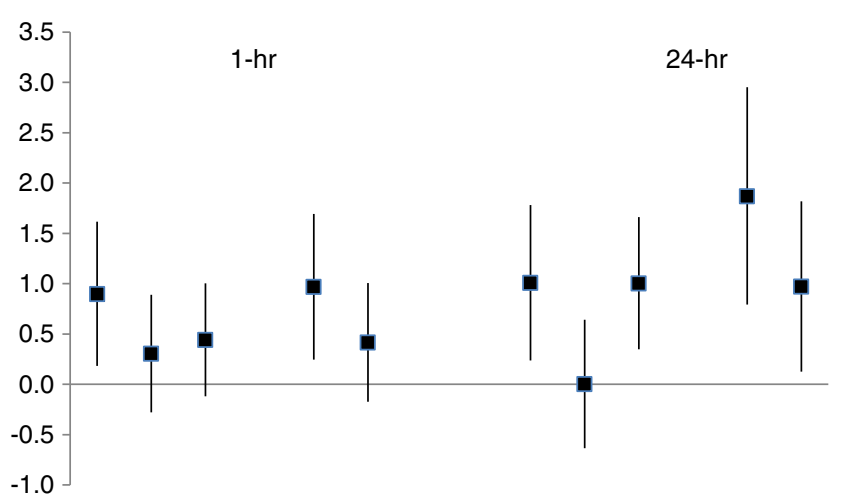

O3 NO2 Ox O3 NO2

O3 NO2 Ox

O3 NO2

Fig. 2 Percentage changes (95\% confidence intervals) in mortality associated with lag 1 day measures of maximum 1-h and mean 24-h concentrations of ozone $\left(\mathrm{O}_{3}\right)$, nitrogen dioxide $\left(\mathrm{NO}_{2}\right)$ and combined oxidant $\left(\mathrm{O}_{\mathrm{x}}\right)$ in single-pollutant models and ozone and nitrogen dioxide in two-pollutant models. a Per $10 \mathrm{ppb}$. b Per interquartile range

the APHEA-2 project reported a little change in the $\mathrm{NO}_{2}$ effect estimate upon adjustment for mean 8-h $\mathrm{O}_{3}$. Attenuation of the (mean 8-h) $\mathrm{O}_{3}$ coefficient (but not the $\mathrm{NO}_{2}$ coefficient) was observed in four Asian cities in the PAPA study (HEI 2010). Other multi-city studies to investigate these pollutants include studies in Spain (Saez et al. 2002), Canada (Burnett et al. 1998) and Australia (Simpson et al. 2005), each reporting little changes in the estimated effects on mortality of 1-h pollutant measures in single- and in two-pollutant models-findings consistent with our results for $1-\mathrm{h}_{3}$ and $\mathrm{NO}_{2}$ - and suggestive of independent effects of the 1-h measures of the two pollutants. Our finding that the magnitude of the singlepollutant model results for 24-h measures of $\mathrm{O}_{3}$ and $\mathrm{NO}_{2}$ increase in two-pollutant models is, given the sparseness of the literature and the variety of averaging times used, difficult therefore to assess in relation to other studies.

$O_{x}$ result versus two-pollutant model results In our study, we found that in the all-year and season-specific associations the $\mathrm{O}_{\mathrm{x}}$ associations were generally comparable to the associations for $\mathrm{O}_{3}$ and $\mathrm{NO}_{2}$ estimated from two-pollutant models. The importance of multi-pollutant approaches for the evaluation of health risks associated with exposures to air pollution has been widely recognised (Johns 2011). Jerret and colleagues noted that (in their recent cohort study of mortality) 'both pollutants need to be in the model for correct inference on either' (Jerret et al. 2013). However, this issue is not straightforward since different amounts of measurement error in the pollutant concentrations can cause biases that require careful adjustment (Zeka and Schwartz 2004). Multi-pollutant models also rely upon other assumptions regarding the linearity of the concentration response function and a lack of seasonal differences in confounding amongst others further complicating their interpretation (Kim et al. 2007). These concerns pose policy makers with problems of interpretation of model results. Based upon atmospheric chemistry alone, there is a strong, a priori, reason for considering $\mathrm{O}_{3}$ and $\mathrm{NO}_{2}$ together in epidemiological studies. From a policy perspective, the use of a single metric for health impact assessment is also appealing as it simplifies health impact calculations and avoids any possible double counting, although the monitoring requirements remain unchanged.

Max 1- $h$ versus 24- $h$ results Few studies have investigated both 1-h and 24-h $\mathrm{O}_{3}$ and $\mathrm{NO}_{2}$ and daily, all-cause mortality within the same dataset. Burnett and colleagues studied both pollutants in 12 Canadian cities and concluded that the daily 1-h concentrations for $\mathrm{NO}_{2}$ displayed a weaker association with daily mortality compared to the daily average values but that 'the daily average value of $\mathrm{O}_{3}$ also displayed a weaker association with mortality than did the daily 1 -h maximum concentration' (Burnett et al. 2004). Studies from North America have tended to focus on 24-h measures of ozone (e.g. analysis of 95 US cities by Bell et al. (2005)), whereas multi-city studies in Europe have used maximum 1- or 8-h measures (Gryparis et al. 2004). In Asia, the large, multi-city PAPA study used 8-h measures (HEI 2010). Our finding of larger associations with 24-h measures compared to 1-h measures in single-pollutant models is therefore new. It suggests that, in our data at least, the longer exposure periods for both pollutants together better characterises daily oxidant exposure although we note that in our study, as in general, the daily measures were highly correlated $\left(r=0.9\right.$ for both $\mathrm{O}_{3}$ and $\mathrm{NO}_{2}$ ).

Mechanism of effects In deciding on an appropriate model or metric to account for the atmospheric chemistry which interchanges $\mathrm{O}_{3}$ and $\mathrm{NO}_{2}$, a consideration of the mechanism of effects is relevant. If both pollutants exert their adverse effects via oxidative stress, then adding them to form $\mathrm{O}_{\mathrm{x}}$ seems particularly relevant. If different mechanisms apply, there is still an argument based on the fundamental atmospheric chemistry for incorporating both $\mathrm{O}_{3}$ and $\mathrm{NO}_{2}$ in the same study, but this could involve either the use of $\mathrm{O}_{\mathrm{x}}$ or a traditional two- 
a)

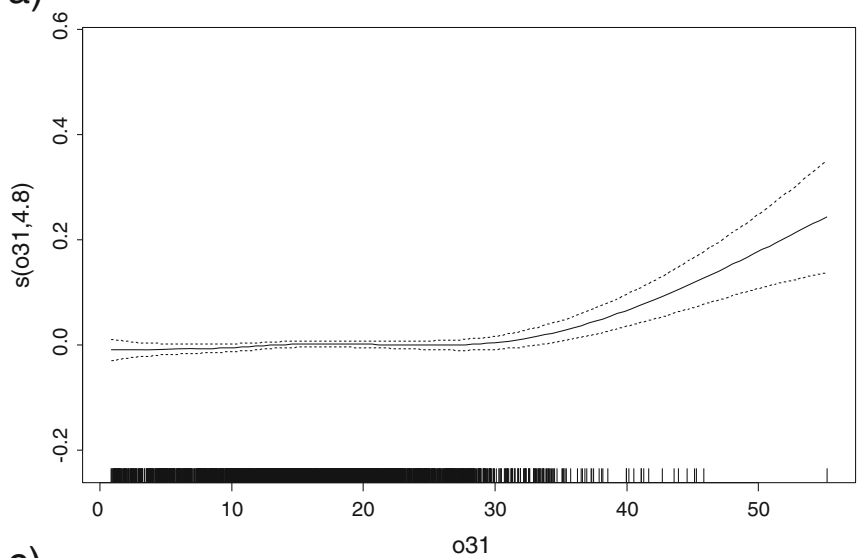

c)

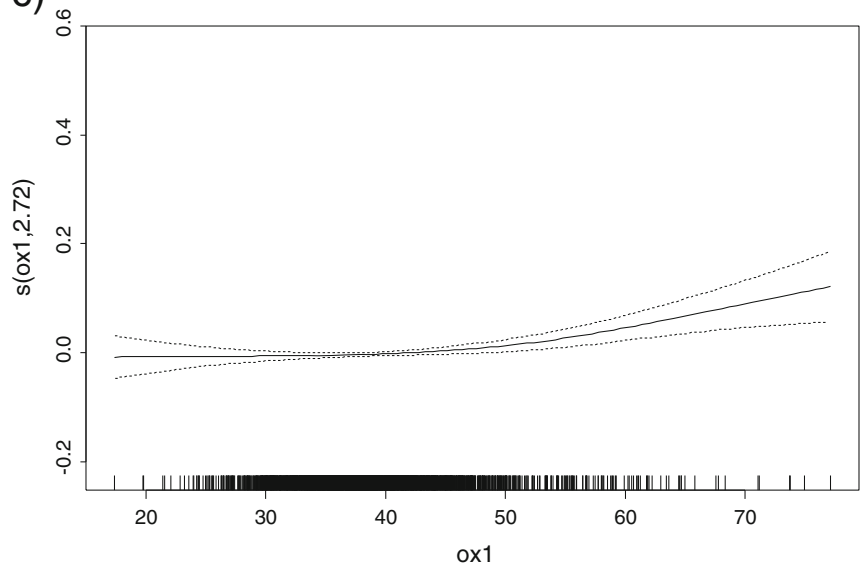

b)

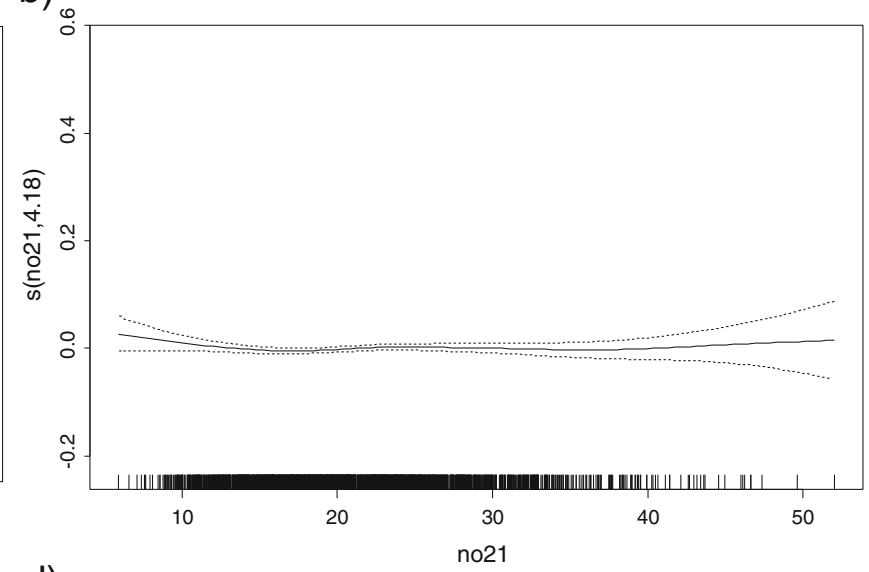

d)

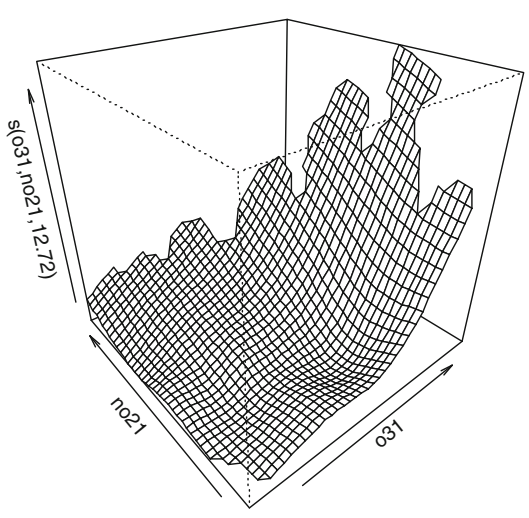

Fig. 3 Concentration response functions for mean 24-h $\mathrm{O}_{3}$ (plot a), $\mathrm{NO}_{2}$ (plot b), $\mathrm{O}_{\mathrm{x}}$ (plot c) and mortality in single-pollutant models and concentration response surface for for $\mathrm{NO}_{2}$ and $\mathrm{O}_{3}$ (plot d)

pollutant model. As well as acting through oxidative stress, it is possible that $\mathrm{NO}_{2}$ could exert its effects also through protein nitration (Matalon et al. 2009). In this case, if $\mathrm{O}_{\mathrm{x}}$ is calculated as a sum of $\mathrm{O}_{3}$ and $\mathrm{NO}_{2}$ weighted by their oxidative potentials, then the effects of $\mathrm{NO}_{2}$ could possibly be underestimated since $\mathrm{O}_{3}$ has a much larger oxidation potential than does $\mathrm{NO}_{2}$. This is discussed further in the next section.

It also needs to be borne in mind that the simple chemistry in Eqs. 1-3 describes the $\mathrm{O}_{3} / \mathrm{NO}_{\mathrm{x}}$ system during much of the year, but during periods of more intense photochemical activity, in so-called 'smog' episodes, more complex chemistry occurs involving reactions of $\mathrm{NO}_{\mathrm{x}}$ and volatile organic compounds (VOCs). These reactions produce intermediates (for example peroxy radicals) and products which could potentially lead to adverse health effects - peroxyacetyl nitrate (PAN) for example is known to exert adverse effects on health. However, the problem for epidemiological studies is that these species are generally difficult to measure so that no routine measurements are currently available.

A further consideration is the fact that in many urban areas the main source of $\mathrm{NO}_{\mathrm{x}}$ and hence $\mathrm{NO}_{2}$ is road traffic, so that $\mathrm{NO}_{2}$ is often closely correlated with particulate matter (PM) and particularly measures of primary PM such as ultrafine particles and elemental and/or black carbon. Further work will be necessary to explore the combined effects of $\mathrm{O}_{3}, \mathrm{NO}_{2}$ and PM.

Alternative weighting for $O_{x}$ As noted in the previous section, in terms of chemical redox potentials, $\mathrm{O}_{3}$ might be expected to be the more powerful oxidant with a redox potential of $2.075 \mathrm{~V}$ compared with a value of $1.07 \mathrm{~V}$ for $\mathrm{NO}_{2}$ (Bratsch 1989). As a measure of combined oxidant, a weighted average of $\mathrm{O}_{3}$ and $\mathrm{NO}_{2}$ may therefore better represent the total impact of the two pollutants on health if oxidative stress is the main mechanism operating for both pollutants. As noted above, however, $\mathrm{NO}_{2}$ may also act via other mechanisms such as protein nitration, so in a sensitivity analysis we recalculated the $\mathrm{O}_{\mathrm{x}}$ metrics using the above weighting. For all-year mortality, the weighted $\mathrm{O}_{\mathrm{x}}$ metric was slightly larger than the unweighted metric but its precision was poorer (data not shown).

Thresholds Another issue of relevance is the question of thresholds - concentrations below which there are very few 
or undetectable health effects. Here, the atmospheric chemistry of the $\mathrm{O}_{3} / \mathrm{NO}_{\mathrm{x}}$ system could clearly be important. As noted above, typical average tropospheric background levels of $\mathrm{O}_{3}$ are around $35 \mathrm{ppb}$, but lower concentrations of $\mathrm{O}_{3}$ occur in urban areas (particularly when $\mathrm{O}_{3}$ 'smog' episodes are not occurring) because of the reaction of $\mathrm{O}_{3}$ with $\mathrm{NO}$, when the $\mathrm{O}_{3}$ is converted to $\mathrm{NO}_{2}$. Investigating the existence or otherwise of a threshold for $\mathrm{O}_{3}$ (and possibly for $\mathrm{NO}_{2}$ although less work has been done to date on this issue) should therefore account in some way for the atmospheric chemistry inherent in the system and should recognise that, particularly in populated urban areas, low ozone concentrations occur because much, or even all, of the ozone is converted to $\mathrm{NO}_{2}$. Singlepollutant studies of ozone which attempt to identify thresholds without taking the $\mathrm{NO}_{2}$ interaction into account may therefore give misleading results. Our preliminary analysis of this issue suggests that the evidence for nonlinearity on the 24-h $\mathrm{O}_{3}$ mortality concentration response relationship reported in this study, and previously in a longer time series for London (Atkinson et al. 2012), remains unaffected by the inclusion of $\mathrm{NO}_{2}$ in the model. This issue has received little attention even in large and influential multi-city studies (e.g. Bell et al. 2006).

Conclusion Our study has demonstrated that the strong interrelationship between daily concentrations of $\mathrm{O}_{3}$ and $\mathrm{NO}_{2}$ suggests that analysis of each pollutant separately does not capture adequately the combined effects on the population from simultaneous exposure to the two interacting pollutants. Based upon atmospheric chemistry alone, there is a strong, a priori, reason for considering $\mathrm{O}_{3}$ and $\mathrm{NO}_{2}$ together in epidemiological studies, rather than either of the two pollutants separately in single-pollutant models. This paper has compared two approaches to this, using $\mathrm{O}_{\mathrm{x}}$, defined as $\mathrm{O}_{3}+\mathrm{NO}_{2}$, as a single metric and also using $\mathrm{O}_{3}$ and $\mathrm{NO}_{2}$ together in twopollutant models. Our work has shown that single-pollutant models of either $\mathrm{O}_{3}$ or $\mathrm{NO}_{2}$ can potentially give misleading results, and some form of combination of the two pollutants needs to be considered in epidemiological studies, either as $\mathrm{O}_{\mathrm{x}}$ or in a two-pollutant model. Furthermore, we suggest that a single metric $\mathrm{O}_{\mathrm{x}}$ has advantages over the traditional twopollutant model approach as it avoids many of the statistical issues associated with such approaches and also simplifies health impact calculations. Also, from a policy perspective, the use of a single metric for health impact assessment is appealing, although the monitoring requirements would remain unchanged. Further work is required to confirm the findings from this study in other cities and countries; other health outcomes and diseases and the potential confounding of these relationships by fine particles. At the very least interactions between ozone and $\mathrm{NO}_{2}$ should be considered carefully in future epidemiological studies and in policy reviews.
Acknowledgments We wish to acknowledge the contribution of Dr. Ian Mudway at Kings College London for the information on the redox potential of $\mathrm{O}_{3}$ and $\mathrm{NO}_{2}$ and to the referees for helpful comments, in particular, regarding the relationships between the choice of metric and model and mechanisms of health effect of the two pollutants.

Open AccessThis article is distributed under the terms of the Creative Commons Attribution License which permits any use, distribution, and reproduction in any medium, provided the original author(s) and the source are credited.

\section{References}

Anderson HR, Atkinson RW, Bremner SA, Carrington J, Peacock J. (2007). Quantitative systematic review of short term associations between ambient air pollution (particulate matter, ozone, nitrogen dioxide, sulphur dioxide and carbon monoxide), and mortality and morbidity. Department of Health. Available: http://www.dh.gov.uk/en/ Publicationsandstatistics/Publications/PublicationsPolicyAndGuidance/ DH 121200

Atkinson RW, Yu D, Armstrong BG, Pattenden S, Wilkinson P, Doherty RM, Anderson HR (2012) Concentration-response function for ozone and daily mortality: Results from five urban and five rural U.K. populations. Environ Health Perspect 120(10):1411-1417

AURN (Automatic Urban and Rural Network). Available: http:/uk-air. defra.gov.uk/data/. [Accessed: June 2010]

BADC (British Atmospheric Data Centre). Available: http://www.badc. nerc.ac.uk/data [accessed June 2010]

Bell ML, Dominici F, Samet JM (2005) A meta-analysis of time-series studies of ozone and mortality with comparison to the National Morbidity, Mortality, and Air Pollution Study. Epidemiol 16:436445

Bell ML, Peng RD, Dominici F (2006) The exposure-response curve for ozone and risk of mortality and the adequacy of current ozone regulations. Environ Health Perspect 114:532-536

Bratsch SG (1989) Standard Electrode Potentials and Temperature Coefficients in Water at 298.15 K. Vol. 18, No. 1, pp. 1-21. Available at http://www.nist.gov/data/PDFfiles/jpcrd355.pdf

Burnett RT, Cakmak S, Brook JR (1998) The effect of the urban ambient air pollution mix on daily mortality rates in 11 Canadian cities. Can J Public Health 89(3):152-156

Burnett RT, Stieb D, Brook JR, Akmak S, Les R, Izenne M et al (2004) Associations between short-term changes in nitrogen dioxide and mortality in Canadian cities. Environ Heal 59(5):228-236

Chardon B, Host S, Lefranc A, Millard F, Gremy I (2007) What exposure indicator should be used to study the short-term respiratory health effect of photochemical air pollution? A case study in the Paris metropolitan area (2000-2003). Environ Risques Santé 6(5):345-353

Clapp LJ, Jenkin ME (2001) Analysis of the relationship between ambient levels of $\mathrm{O}_{3}, \mathrm{NO} 2$ and $\mathrm{NO}$ as a function of NOx in the UK. Atmos Environ 35:6391-6405

Gryparis A, Forsberg B, Katsouyanni K, Analitis A, Touloumi G, Schwartz J et al (2004) Acute effects of ozone on mortality from the "Air Pollution and Health: a European Approach" project. Am J Respir Crit Care Med 170:1080-1087

HEI Public Health and Air Pollution in Asia Program (2010) Public Health and Air Pollution in Asia (PAPA): coordinated studies of short-term exposure to air pollution and daily mortality in four cities. HEI Research Report 154. Health Effects Institute, Boston

Jerret M, Burnett RT, Beckerman BS, Turner MC, Krewski D, Thurston G, Martin R, von Donkelaar A, Hughes E, Shi Y, Zapstur SM, Thun 
MJ, Arden Pope C III (2013) Spatial analysis of air pollution and mortality in California. Am J Respir Crit Care Med 188:593-599

Johns D (2011) Overview of EPA Multipollutant Science and Risk Analysis Workshop: February 22-24, 2011, Chapel Hill, NC. http://www.epa.gov/ncer/publications/workshop/04_07_2011/ presentations.html [Accessed July 2013]

Kim JY, Burnett RT, Neas L, Thurston GD, Schwartz J, Tolbert PE, Brunekreef B, Goldberg MS, Romieu I (2007) Panel discussion review: Session two $\mathrm{F}$ interpretation of observed associations between multiple ambient air pollutants and health effects in epidemiologic analyses. J Expo Sci Environ Epidemiol 17:S83-S89

Matalon S, Shrestha K, Kirk M, Waldheuser S, Mcdonald B, Smith K, Gao Z, Belaaouaj A, Crouch EC (2009) Modification of surfactant protein $\mathrm{D}$ by reactive oxygen-nitrogen intermediates is accompanied by loss of aggregating activity, in vitro and in vivo. FASEB J 23: $1415-1430$

Monks PS et al (2009) Atmospheric composition change-global and regional air quality. Atmos Environ 43:5268-5350

R, Development Core team, 2007

Saez M, Ballester F, Barcelo MA, Perez-Hoyos S, Bellido J, Tenias JM et al (2002) A combined analysis of the short-term effects of photochemical air pollutants on mortality within the EMECAM project. Environ Health Perspect 110(3):221-228

Samoli E, Aga E, Touloumi G, Nislotis K, Forsberg B, Lefranc A et al (2006) Short-term effects of nitrogen dioxide on mortality: an analysis within the APHEA project. Eur Respir J 27(6):1129-1137
Seinfeld JH, Pandis SN (2006) Atmospheric chemistry and physics-from air pollution to climate change, 2nd edn. Wiley, New York

Simpson R, Williams G, Petroeschevsky A, Best T, Morgan G, Denison L et al (2005) The short-term effects of air pollution on daily mortality in four Australian cities. Aust N Z J Public Health 29(3):205-212

Touloumi G, Katsouyanni K, Zmirou D, Schwartz J, Spix C, De Leon AP et al (1997) Short-term effects of ambient oxidant exposure on mortality: a combined analysis within the APHEA project. Air pollution and health: a European approach. Am J Epidemiol 146(2):177-185

Van Egmond ND, Kesseboom H (1985) A numerical mesoscale model for long-term average NOx and NO2 concentrations. Atmos Environ 19(4):587-595

WHO 2013 Review of evidence on health aspects of air pollution REVIHAAP Project: Final technical report. Available at: http:// www.euro.who.int/en/what-we-do/health-topics/environment-andhealth/air-quality/publications/2013/review-of-evidence-on-healthaspects-of-air-pollution-revihaap-project-final-technical-report (Accessed Jul 2013)

Wood S.N. (2006) Generalized Additive Models: An Introduction with R. Chapman and Hall/CRC Press

Zeka A, Schwartz J (2004) Estimating the independent effects of multiple pollutants in the presence of measurement error: an application of a measurement-error-resistant technique. Environ Health Perspect 112(17):1686-1690 